
DIVERGENCE

\author{
Rafael Dobado-González \\ Alfredo García-Hiernaux \\ David Guerrero-Burbano
}

Working Papers / Documentos de Trabajo. ISSN: 2255-5471

DT CCEE-1308

Julio 2013

http://eprints.ucm.es/22528/ 


\title{
WEST VERSUS EAST: EARLY GLOBALIZATION AND THE GREAT DIVERGENCE
}

\begin{abstract}
:
This paper extends our previous work on grain market integration across Europe and the Americas in the eighteenth and nineteenth centuries (Dobado, García-Hiernaux and Guerrero, 2012). By using the same econometric methodology, we now present: 1) a search for statistical evidence in the East of an "Early Globalization" comparable to the one ongoing in the West by mid eighteenth century; 2) a study on the integration of grain markets in China and Japan and its functioning in comparison to Western countries; 3) a discussion of the relevance of our findings for the debate on the Great Divergence. Our main conclusions are: 1) substantial differences in the degree of integration and the functioning of grain markets are observed between East and West; 2) a certain degree of integration may be reached through different combinations of factors (agents, policies, etc.) and with dissimilar effects on long-run economic growth; 3) the absence of an "Early Globalization" in the East reveals the existence of some economic and institutional limitations in this part of the world and contributed to its "Great Divergence" with the West from at least the eighteenth century.
\end{abstract}

Keywords: Economic history, Market integration, Globalization, Great divergence, Time series analysis

\section{OESTE FRENTE A ESTE: GLOBALIZACIÓN TEMPRANA Y GRAN DIVERGENCIA}

\section{Resumen:}

Este trabajo expande nuestra investigación previa sobre la integración del mercado de granos en Europa y América (Dobado, García-Hiernaux y Guerrero, 2012). Usando la misma metodología econométrica, presentamos ahora: 1) la búsqueda de evidencia estadística en el Este de una "Globalización temprana" semejante a la encontrada en el Oeste desde mediados del siglo XVIII; 2) un estudio de la integración de los mercados en china y Japón y su funcionamiento en comparación con los países occidentales; 3) una discusión de la relevancia de nuestros resultados respecto al debate sobre la "Gran Divergencia". Nuestras principales conclusiones son: 1) encontramos diferencias sustanciales entre Este y Oeste en lo que al grado de integración y al funcionamiento de los mercados de grano se refiere; 2) un cierto grado de integración puede ser alcanzado mediante combinaciones diferentes de factores (agentes, políticas, etc.) y con efectos distintos sobre el crecimiento económico a largo plazo; 3) la ausencia de una "Globalización temprana" en el Este revela la existencia de limitaciones económicas e institucionales en esta parte del mundo y contribuyó a la "Gran Divergencia” con el Oeste desde al menos el siglo XVIII.

Palabras clave: Historia económica, Integración de mercados, Globalización, Gran divergencia, Series temporales.

Materia: Historía económica

JEL: C22, F15, N10, N70

\author{
Rafael Dobado-González \\ Departamento de Historia e \\ Instituciones económicas II \\ Facultad de CC. Económicas y \\ Empresariales. Universidad \\ Complutense de Madrid \\ Campus de Somosaguas, 28223 \\ Pozuelo de Alarcón (Spain) \\ E-mail: rdobado@ccee.ucm.es
}

\author{
Alfredo García-Hiernaux \\ Departamento de Fundamentos y \\ Análisis Económico II. \\ Facultad de CC. Económicas y \\ Empresariales. Universidad \\ Complutense de Madrid \\ Campus de Somosaguas, 28223 \\ Pozuelo de Alarcón (Spain) \\ E-mail: agarciah@ucm.es
}

\author{
David Guerrero-Burbano \\ Centro Universitario de Estudios \\ Financieros, Madrid \\ E-mail: d-guerrero@cunef.edu
}

Julio 2013 (fecha de recepción)

Rafael Dobado- González acknowledges support from the Ministry of Education of Spain under grant ECO201126286.

Alfredo García-Hiernaux acknowledges support from Ramón Areces Foundation. 
This paper presents a preliminary attempt at contributing to two important brands of economic literature: 1) Globalization (i.e., international market integration); and 2) “Great Divergence” between East and West. It does so by means of a twofold research strategy that combines theoretically-based (Law of One Price) econometric work with empirically well-founded, albeit somewhat speculative, traditional economic history.

It is our contention that the absence in the East of the intra- and intercontinental grain market integration found by Dobado et al. (2012) in the West as early as by mid eighteenth century may be interpreted as a form of Western exceptionalism. We identify several significant dissimilarities between West and East concerning grain market integration: geo-economic scope (intra- and intercontinental versus national); evolution over time (secular progress versus reversal in the nineteenth century); role of agents (market forces versus state and others as leading forces) and policies (relative openness to foreign trade versus relative closeness). Therefore, West and East were different in this important respect both before and after the Industrial Revolution.

The restrictive trade policy practiced by the East (China, Japan and Korea) might have been one of the biggest economic policy mistakes ever committed since it prevented that part of the world from taking advantage of the direct (static and dynamic gains) and indirect (institutional) benefits resulting from the expansion of foreign trade during the Early Modern Era.

However, in spite of its importance, the absence of international grain market integration has not yet considered in the debate on the "Great Divergence". Basically based on the pursuit of internal policy goals, the closing of the Eastern economies during the Early Modern Era has been one of the biggest mistakes of economic policy ever made since it contributed to the "Great Divergence” well before 1800.

Aside from this introduction, the paper comprises: 1) a first section in which the historical processes of Globalization and Great Divergence are discussed; 2) a second section that presents the econometric methodology and the main results of our empirical work; and 3) a summary of our chief conclusions in the third section. 


\section{Globalization and Great Divergence}

When did globalization start? The answer to this question depends on how globalization is defined. De Vries (2010) distinguishes between "soft" and "hard" globalization. Flynn and Giráldez claim that "soft globalization" started "when the Old World became directly connected with the Americas in 1571 via Manila." 1 "Hard globalization” is defined by O'Rourke and Williamson as “integration of markets across space". ${ }^{2}$ For well-founded theoretical and empirical reasons, this definition is more popular among economists. Therefore, it is the one adopted here. Then, globalization started in the West by the first half of the eighteenth century when grain markets became increasingly integrated within Europe and between Europe and the US -see Dobado, García-Hiernaux and Guerrero (2012). ${ }^{3}$

Our econometric methodology, supplemented with substantial historical evidence, permits us to offer a new perspective on the globalization process that somewhat differs from one established in their pioneering works by O’Rourke and Williamson (1999, 2002a, 2002b and 2004) -see Figure 1 and Figure 2. Thus, starting in the first half of the eighteenth century, globalization predated rather than followed the first instance of modern economic growth, the Industrial Revolution. This important finding might have been previously overlooked because intercontinental market integration was interrupted by the French Revolutionary and Napoleonic Wars (17921815) and their aftermath. ${ }^{4}$ When globalization regained momentum, it then coincided with -and was favoured by- the spread of the Industrial Revolution throughout Europe and the US. We term the pre-1792 intra- and intercontinental integration of grain markets as “Early Globalization”. Latin American countries, with the possible partial exception of Chile due to its trade on wheat with Peru, did not join the "Early Globalization”.

The dramatic expansion of foreign trade across the West in the Early Modern Era delivered significant economic benefits. The direct impact of foreign trade (e.g. via

\footnotetext{
${ }^{1}$ Flynn and Giráldez, 2004, p. 82.

${ }^{2}$ O’Rourke and Williamson, 2004, p. 109.

${ }^{3}$ Throughout this paper, despite its vagueness, the term "West" refers to the US and Europe, not including the Ottoman Empire. "East" is also a vague concept. Hereinafter, "East" means China and Japan. On top of deep historical reasons, that meaning is consistent with the content of this paper. India has been consciously left outside that "East".

${ }^{4}$ O'Rourke (2006) has shown the disruptive effects of this cycle of wars on the Atlantic economy but might have underestimated the level of market integration effectively reached in the West prior to the early 1790s.
} 
specialization, expansion of internal markets, etc.) on economic growth has been recognized since long time ago by economists. In this respect, despite all due qualifications, the contrast between a relatively "open” West and a relatively "closed" East (e.g., haijin and cohong in, respectively, Ming and Qing China and sakoku and kaikin in Tokugawa Japan) is apparent. ${ }^{5}$ Adam Smith wrote that the "Chinese have little respect for foreign trade" ${ }^{6}$. The seclusion policy set in place by the edicts of the 1630's is one of the main characteristics of Tokugawa Japan.

The West relative openness resulted into a dynamic Atlantic trade -the Baltic and the Mediterranean being interconnected to it- on which the Early Globalization was based. Additionally, the Atlantic trade significantly contributed through an indirect institutional channel to the "First Great Divergence": the unprecedented economic growth that Europe experienced between 1500 and 1800 (Acemoglu, Johnson and Robinson, 2005). ${ }^{7}$ According to these authors, large profits generated by the Atlantic trade, especially in Britain and the Netherlands, increased the political bargaining power of the commercial interests which induced significant institutional change of the type (i.e. secure property rights) that favoured economic growth in pre-industrial Europe. Moreover, Morris (2010) suggests that the challenge represented by the "Atlantic frontier" acted as a powerful incentive for the West to find scientifically-based answers to practical problems. By doing so, it promoted divergence from the East in long-term social -and economic- development since the early 1770's "or thereabouts". On the contrary, the "steppe frontier" proved much less stimulating for China. In spite of its importance, the growing overland trade with Russia in the eighteenth century -that somewhat substituted for the declining Silk Road- was even smaller than the limited maritime commerce that took place at Canton under the cohong system with the earlyglobalized Western countries. ${ }^{8}$

\footnotetext{
${ }^{5}$ In spite of Western mercantilism, trade policies in China or Japan were incomparably more restrictive, including from phases of autarchy or very limited contact with foreigners to the total evacuation of some coastal areas of South-eastern China -see Findlay and O’Rourke (2007).

${ }^{6}$ Taken from Millar, 2011, p. 205. This author finds in European sources "a consistent narrative of frustration" originated by the meeting between "European ambitions of achieving a bountiful of trading relationship with China, met with the reality of Chinese restrictions.” Ibidem, pp. 206-207.

7 "Atlantic trade", in these authors' opinion, "means trade with the New World, as well as trade with Asia via the Atlantic, and includes colonialism- and slavery-related activities" (Acemoglu et al., 2005, p. 546). However, the growing integration across the "early globalizing West" (i.e., an imprecise, changing, and porous space stretching from Pennsylvania to the Danzig-Vienna-Milan arch -see Dobado et al. (2012)-) could not but to reinforce the institutional effect of the "Atlantic trade" à la Acemoglu et al. (2005). Actually, trade within Western Europe alone was bigger than with the rest of the world circa 1790 (O’Rourke, Prados and Daudin, 2008).

${ }^{8}$ See Findlay and O’Rourke, 20007, pp. 284-300.
} 
That the increase in foreign trade contributed to economic growth in Meiji Japan is widely accepted by economists and economic historians. According to Bernhofen and Brown (2005), the static gains to Japan resulting from the opening-up of its economy were close to ten per cent of the GDP. Recently, Keller, Li and Shiue (2012) have shown the importance of the opening of China to foreign trade through Shanghai after the Opium War for the long-run growth performance of the country.

The idea that the East had fallen behind the West economically before the Industrial Revolution is long lasting and influential. ${ }^{9}$ Nonetheless, since the late 1990s it has been challenged by a stimulating revisionist view on the comparative levels of economic development at the two ends of Eurasia. ${ }^{10}$ As a consequence of its criticism to aspects of previous explanations of the rise of Europe, further quantitative research has been conducted. It has yielded interesting results. Some of them are relevant to the aim of this paper. The beginning of the "Early Globalization" seems to have occurred at a point in time when indications of the Great Divergence between West -or at least its most advanced parts- and East can be found. In the eighteenth century, living standards in London and Amsterdam were higher than in Chinese (Suzhou, Beijing and Canton) or Japanese (Kyoto/Tokyo) towns (Allen, Bassino, Ma, Moll-Murata and Van Zanden, 2011). These authors conclude that the comparisons of living standards "paint a less optimistic picture of Asian performance than the revisionists suggest." ${ }^{11}$ This conclusion is consistent with the turning point observed "somewhere between 1750 and 1800 " in the respective regional values of the index of social development built by Morris (2010): for the first time since the sixth century, the East was surpassed by the West. $^{12}$

$\mathrm{Li}$ and Van Zanden (2012) estimate that differences between two of the most advanced economies in Europe and China (the Netherlands and Hua-Lou, part of the Yangtze delta, respectively) were significant already in the 1820s. GDP per capita was almost ninety per cent higher in the Netherlands than in the Hua-Lou area. Moreover, these authors suggest that in 1820 -it is to say, before the spread of the Industrial Revolution across the Continent - relative GDP per capita between Western Europe and

\footnotetext{
${ }^{9}$ See, among others, Weber (1905:1930), Jones (1981, Landes (1998, 2006) and Maddison (2007a, 2007b).

${ }^{10}$ I.e., Wong (1997), Frank (1998), Pomeranz (2000) and Goldstone (2008).

${ }^{11}$ Allen et al., 2011, p. 9.

${ }^{12}$ Morris, 2012, p. 482. Morris' index of social development accounts for four dimensions (energy capture, urbanization, war-making and information technology).
} 
China might be not far from the one estimated by Maddison. ${ }^{13}$ As to Japan, Bassino et al. (2011) find that the GDP per capita was less than half that of Great Britain by 1700 while in 1800 it had lowered to thirty per cent despite its relatively fast growth since 1850.

However, the revisionist view on the comparative levels of development in East and West before the Industrial Revolution retains much of its intellectual appeal and influence. Besides, there still remain a lot of unanswered questions about the economic performance of these two parts of the world in the Early Modern Era. One of great interest among them is whether "Early globalization" in the West and "Great Divergence” between East and West are causally related. Our hypothesis is that they are. On the one hand, "Early Globalization” required a certain level of effective political, institutional, economic and technological development applied to the functioning of grain markets across national borders. On the other hand, since wellfunctioning markets are necessary for economic growth, "Early Globalization” similarly to the subsequent phases of the process in the nineteenth and twentieth centuries, albeit less intensely- therefore favoured divergence between those countries or regions that took part in it and those that did not. Thus, "Early Globalization” was made possible by pre-existing differences between West and East (i.e. better institutions and policies to promote foreign trade intensification) and contributed to widen the initial gap in GDP per capita between East and West through the direct and indirect economic benefits delivered to the latter, but not, or very much less so, to the former by international commerce.

In our view, "Early Globalization” is a particular form of Western exceptionalism. This exceptionality consisted of economic policies that supported wellfunctioning national and international markets and therefore fostered. However, the very idea of any Western exceptionalism conflicts with the basic conclusions by the revisionist school. In particular, regarding grain market performance and, more generally, markets allocative efficiency, Shiue and Keller (2007) convincingly claim that "as to the period right before the Industrial Revolution took place in Western Europe, grain markets did not perform uniformly better in Western Europe than in

\footnotetext{
${ }^{13}$ The ongoing revision of the economic growth before 1820 by the Maddison Project takes into consideration new quantitative research on the GDP per capita levels in Eurasia and basically confirms the pre-revisionist view of Angus Maddison on the gap between East and West -see Bolt and Van Zanden, 2013.
} 
China.” ${ }^{14}$ Bassino (2007) also concludes that markets in Japan between 1717 and 1857 "were fairly well integrated". ${ }^{15}$ Thus, as in other domains, any Western superiority needs to be empirically demonstrated rather than a priori assumed. We try to do that by studying market integration in some selected grain markets in China and Japan.

The main novelties in this paper with respect to others dealing with market integration in the East are firstly of methodological order. Our econometric approach provides a metrics that can be used to estimate and compare the integration between markets in a given year as well as over a short, medium or long period. Besides, we take into account not only domestic market integration but also, and especially, international (intra-and intercontinental) market integration in both East and West. Developments occurred in the nineteenth-century are considered as well. Additionally, we pay attention to the differences in terms of agents of the integration: 1) the leading role of the "high Qing” state in the circulation of grain throughout the empire; 2) the basically feudal origin of most of the rice traded by the brokers that operated in the sophisticated Dojima market of Osaka. Differences in the historical context in which integration was reached (e.g., agents, market power and trade policies) matters since they had varied consequences for modern economic growth in the East and the West.

Our study confirms the accuracy of the findings by Shiue and Keller (2007) and Bassino (2007). Besides, it complements them by showing some of the limitations of the grain market integration reached in the East: mainly, its national, not international, geo-economic scope and its stagnation or reversal in the nineteenth century. We infer that these limitations are relevant regarding the explanation of why the Great Divergence between East and West took place before the Industrial Revolution.

\section{Econometric methodology and empirical results}

In this section, we present the sample of grain (wheat and rice) price series used and the methodology, models and results of our statistical analysis.

We consider markets for wheat in the West: three not yet considered in England (Eton, Exeter and Winchester) and those (Amsterdam and Holland, Arévalo, Gdansk, London and Southern England, Milan, Pennsylvania, Strasbourg and Vienna)

\footnotetext{
${ }^{14}$ Shiue and Keller, 2007, p. 1205.

${ }^{15}$ Bassino, 2007, p. 19.
} 
previously analyzed in depth in Dobado et al. (2012). On the other side, we also include in the sample eleven markets for rice in the East: eight in Japan (Osaka, Fukuchiyama, Bocho, Kumamoto, Nagoya, Aizu, Rural Banshu, Hiroshima, Saga Edo, Shinshu and Dewa) and three in China (Yangtze river delta, Jiangsu and Hunan). The selection of markets responds to a mixed criterion: data availability and geographical representativeness. The markets in England, Japan and China will be mainly used with the purpose of a national integration comparison. The rest of the markets will be used for the purpose of inter- and intracontinental comparison. We work with long yearly data series covering most of the eighteenth and the nineteenth centuries for most markets. Data sources are shown in Appendix 1. ${ }^{16}$

As units of measure, we convert original prices into prices in terms of grams of silver per liter for both West and East.

The steps of our methodology for analyzing the evolution of market integration are presented in Table 1. A detailed explanation can be found in Dobado et al. (2012). Broadly speaking, we check that (log) nominal prices are cointegrated and follow the Law of One Price (LOP), through nonstationarity tests applied to the logarithm of nominal and relative prices $\left(\log \left(P_{i t}\right)\right.$ and $\log \left(P_{i t} / P_{j t}\right)$, respectively). ${ }^{17}$ When nominal prices are cointegrated, we take advantage of the fact that the more integrated a market is the less effect unpredictable shocks have on relative prices between pairs of markets. Bearing that in mind, we study the evolution over time of the dispersion of the residuals obtained from fitting an ARMA model to relative prices. Obviously, if two nominal prices have different order of integration then the LOP does not hold and we conclude that they cannot be integrated from an economic point of view.

Our analysis starts by studying the nonstationarity of all (log) nominal grain prices included in the sample. In a second step, we test the nonstationarity of (log) relative prices for every combination of wheat/rice nominal prices that were previously identified as I(1). By first confirming the I(1) property of nominal prices and then the stationarity of relative prices, the cointegrating relationship and cointegration parameter equal to -1 are jointly tested, which is conceptually preferable and statistically more

\footnotetext{
${ }^{16}$ We acknowledge the generosity of those authors that made available their own and others' data to the academic community through the web pages of the International Institute for Social History and the Global Price and Income History Group. Allen's work deserves special recognition regarding our work. All authors to which we are grateful are mentioned in Appendix 1.

${ }^{17}$ Series of nominal or relative prices are logarithmically transformed to avoid heteroskedasticity related to increasing mean. We test the nonstationarity using Shin and Fuller (1998) statistic on a fitted ARMA model.
} 
efficient. The cointegration relationship between two (log) nominal prices with cointegrating parameter equal to -1 is closely related to the LOP. If the log price differential is stationary, $\log \left(P_{i t}\right)-\log \left(P_{j t}\right)=\square_{j t}$, where $\square_{j t}$ is a zero-mean stationary process, then the $\log$ relative price is also stationary, $\log \left(P_{i t} / P_{j t}\right)=\square_{j t}$. The latter is the mathematical representation of the stochastic and dynamic notion of the LOP in strong form: in an efficient market, all identical goods have the same price in the long run. However, the empirical analysis will show that the relative prices analyzed suffer transitory fluctuations around a long run constant nonzero mean. This situation refers to a weaker version of the LOP that permits imperfect competition, trade barriers and transport costs. The effect of these transaction costs in relative prices is captured by the nonzero mean. From now on in the paper, the term LOP will always refer to this weaker form. We therefore agree with Persson (1999), Ejrnaes and Persson (2000) and Shiue and Keller (2007) that cointegration provides substantial evidence in favor of market integration. ${ }^{18}$ However, in our paper we are more demanding, as we also require the cointegration parameter to be equal to -1 , i.e., we require the LOP to hold. This part of our analysis encompasses steps 1 and 2 in Table 1.

If the hypothesis that LOP holds cannot be rejected -and only in that case-, we then focus on the dispersion of the unpredictable shocks affecting the relative prices. In this third step of our empirical analysis, we interpret the residuals of the (log) relative price univariate models as the net idiosyncratic shocks of the nominal prices. Földváry and Van Leeuwen (2010) convincingly discuss the advantages of using the dispersion of these residuals instead of other commonly utilized statistical approaches -e.g., coefficients of variation- for measuring market efficiency. In this respect, the residual variance will reflect the share of unforeseeable shocks in total variance, i.e., the effect of unexpected events on relative price volatility. If markets are very integrated, unexpected events on the nominal prices should have a reduced effect on relative prices. Consequently, decreasing trend-like behavior in the Standard Deviation of the Innovations (SDI) of the relative prices between pairs of markets will be interpreted as an increasing market's ability to cope with the effect of shocks on nominal prices and therefore as increasing integration between those pairs of markets

Finally, the study of the residual dispersion obtained from the estimated (log) relative price models was carried out through the evolution over time of the SDI

\footnotetext{
${ }^{18}$ However, the economic interpretation of cointegration is not self evident -see Federico (2008). We agree with him that cointegration is not a sufficient condition of market integration.
} 
calculated with rolling windows of 35 observations for every relative price (e.g., Osaka/Edo, Pennsylvania/London, etc.). ${ }^{19}$ In any figure where the SDI is drawn (see, for instance Figure 1), each point at year $t$ represents the standard deviation of that residual and the previous thirty-four residuals.

Our methodology is based on the ARMA representation of the price series. ${ }^{20} \mathrm{We}$ find that all the $\log$ nominal prices, $\log \left(P_{i t}\right)$, present a stochastic trend that can be removed by taking differences, i.e., they are integrated of order one.

We only use univariate analysis of log relative prices to study pairwise cointegration relationships between markets. This has a clear advantage with respect to VAR, VARMA or any other multivariate representation in terms of simplicity in the specification and interpretation. The empirical identification for $\log \left(P_{i t} / P_{j t}\right)$, where $P_{i t}$ and $P_{j t}$ represent two log nominal wheat (or rice) price series, reveals that most log relative prices are stationary, i.e., integrated of order zero. In these cases the cointegration with cointegrating parameter equal to -1 is confirmed (i.e., the West). A significant exception must be pointed to this result: the Chinese rice series are not cointegrated with the Japanese ones.

Our main empirical findings and their interpretation are enumerated below:

1) The econometric analysis shows that the markets in England were highly integrated. The evolution of the SDI of the residuals obtained from the ARMA models of the log relative prices (which is our dynamic measure of integration) confirms this fact. Figure 3 shows that the integration reached levels of $4 \%$ and below before 1800 . This is not surprising, as England probably was the most integrated -and certainly the most dynamic- economy of the world by that time. What could be more surprising is that Jiangsu and Yangtze Delta River, which are 185 miles far from each other -quite similar to the 170 miles distance between Eton and Exeter-, were nearly as integrated as the English ones by 1800 -see Figure 4. This result coincides with those presented by Shiue and Keller (2007) about the comparison between the integration level in some Chinese provinces and England around the end of the eighteenth Century. On the other hand, markets in Japan show a significant national integration level as well, which is

\footnotetext{
${ }^{19}$ Different values for the size of the rolling window were tried. Obviously, the higher are the values, the smoother are the series. This does not change the trend of the standard deviations but the minimum and maximums are more difficult to identify.

${ }^{20}$ The specification is carried out using simple and partial autocorrelation functions, and AIC (Akaike, 1974) and HQ (Hannan and Quinn, 1979) information criteria. The results of the parameter estimation and hypothesis tests are reported in Appendix 2, Table A.2. Additionally, we carried out an analysis with the same series in local currencies that is available from the authors upon request. The findings were very similar and the conclusions do not vary significantly.
} 
consistent with Bassino (2007). As an example, the integration degree between Osaka and Hiroshima (within a distance range of less than 200 miles from each other and therefore comparable with the representative markets selected for China and England) stays consistently below $10 \%$ during the second half of the eighteenth century -see Figure 5. That level was certainly higher than those of Eton/Exeter and Jiangsu/Yangtze, but still indicates a significant degree of integration if compared with that between markets in different continents in the West -see Figures 1 and 2- estimated by Dobado et al. (2012); or, as could be expected, with respect to other, more distant pairs of domestic markets in Japan (as can be seen in Figure 5). Thus, national integration level was relatively similar (at least in short or medium distances) in England, China and Japan (being a little bit lower in the latter).

Regarding integration between less proximate markets in China and Japan, we can see that distance was an important drawback: the integration degree between Yangtze/Hunan or Osaka/Aizu (about 675 and 400 miles away from each other, respectively) was considerably lower than in the above-mentioned cases of closer proximity (see Figures 4 and 5). Albeit distance -as well as geographical obstaclesalways constitutes an impediment to market integration, it was probably much more so in Japan than in China or England because they were reinforced by intentional measures taken by the government such as the prohibition of constructing large tonnage vessels (Bassino, 2007), restrictions on wheeled traffic (Vaporis, 1994), etc.

2) In this second point we deepen in how these three countries (England, China and Japan) reached substantially high national degrees of integration. We will briefly explain the main differences between the fundamentals of markets functioning that led to domestic markets integration. Behind the different levels and dynamics of grain market integration across East and West we find three institutional models: i) markets (domestic as well as foreign) had since relatively early in the eighteenth century a much more important role as allocative mechanisms in Europe and the US ("market-led integration”); ii) in China the state, through tribute in kind, ever normal granaries, stock accumulation, public works, relief policy, etc., was the leading force, especially during the "golden Qing” epoch, behind the systematic redistribution of grain between (basically from South to North) and within (mainly in Northern areas) regions and economic groups (from producers to consumers) in a rather than not closed economy 
(“state-controlled integration”); ${ }^{21}$ iii) Tokugawa Japan presents a nearly autarchic economy in which rice originated as feudal payments by peasants to the samurai class reached a well-integrated and sophisticated market (in Osaka, the world first futures markets was regulated by the Shogunate as early as in 1730) ("feudal/Dojima integration”).

Thus, significant levels of national grain markets integration were achieved in different ways and with diverse short and long term effects on the economic behaviour of grain consumers and producers and, hence, on the ability of the country's economy to generate modern economic growth. The Chinese "state-controlled integration" seems to have been more efficient at limiting the consequences of bad harvests on the commoners. However, in the nineteenth century, it could barely survive to the loss of political and economic power by the state and did not favor the modernization of the Chinese institutional framework during the late Qing dynasty. ${ }^{22}$ In Japan, a domestic rice market isolated from foreign competition and dominated by the landing class caused a high price level that in turn was at the bottom of social unrest and hurt the economy of Tokugawa Japan. The Western model was less sophisticated than the Japanese and, especially during the transition from medieval to modern regulation of grain markets, inferior to the Chinese at providing relief in case of famine. Notwithstanding, it proved to be more conductive for raising living standards in the long run and bringing about sustainable economic growth.

3) In this third argument we relate the previous point and new findings with the Great Divergence. As we have shown above, one possible reason that could have contributed to the Great Divergence was the completely different institutional (agents and policies) mechanisms that drove the national integration in West and East. Now we present a second important finding that supports this fact and add another argument to explain the divergence between these two parts of the world. Coming back to England, our econometric results show that not only the domestic integration was high and increasing along the eighteenth and nineteenth centuries, but also the international (continental and intercontinental) integration improved quickly. Dobado et al. (2012) show that Europe and British North-America increased their intercontinental integration levels during the second half of the eighteenth century -see Figures 1 and 2. This

\footnotetext{
${ }^{21}$ See among others Will (1990), Wong (1997), Shiue (2005) and Li (2000, 2007).

${ }^{22}$ In contrast with long-term fiscal developments in the Western countries, the Qing state collected the same amount of per capita tax revenue in terms of grams of silver in 1650-1699 as in 1850-1899 (Brandt et al. 2012).
} 
process was interrupted by the French Revolutionary and the Napoleonic Wars and was kept in a standby position during the Corn Laws. However, the process resumed faster than before from the middle of the nineteenth century to the end of the Century. Figure 1 and Figure 2 illustrate how the effect of distance and other transaction costs on integration decreased as a result of the canonical period of globalization. By 1900, the degree of market integration between Holland/London and Pennsylvania/London reached levels of roughly $7 \%$.

On the contrary, nothing similar occurred in the East. As a matter of fact, when we analyze the relation between rice Japanese and Chinese markets, the cointegration is clearly rejected. ${ }^{23}$ No statistical -neither historical for that matter- evidence is found of any similarity whatsoever in the long-run behavior of rice prices between these two countries, despite being separated by about 560 miles (from Yangtze to Kagoshima) across the East China Sea. This finding is quite surprising since an almost permanent positive differential in prices existed between Osaka and the Yangtze river delta. This differential was higher than the one existing between Western markets. It is then difficult to understand the economic rationale, if any, behind the absence of grain trade from China to Japan. Moreover, on top of the quasi-constant differential in prices that would explain systematic exports of rice from the Yangtze delta river to Osaka, occasional short-term changes in the relative price between the two markets were large enough as to make punctual arbitrage potentially very profitable. This substantial potential for trade within the East was far from being exploited during the Early Modern Era. On the contrary, the institutional framework of the Early Modern Era allowed for trade policies in the West that made possible to exploit narrower margins for commercial profits.

The disconnection between markets within the East was caused by the restrictive trade policies adopted by the Qing and Tokugawa states. These policies responded basically to political goals and contrast with those that were being adopted in the West and resulted in the "Early Globalization" that becomes, then, a form of Western exceptionalism in terms of market functioning and allocative efficiency. Important as it is, the absence of international integration of grain markets in the East during the eighteenth century has not yet played any part in the debate on the "Great Divergence".

\footnotetext{
${ }^{23}$ The results of the unit roots and cointegration analyses for all the (log) nominal and relative price series are documented in an appendix that can be downloaded from the web page www.ucm.es/info/ecocuan/agh/
} 
However, it prevented China and Japan from obtaining the direct and indirect economic benefits delivered to the West by the increase in foreign trade before the Industrial Revolution and contributed to the "Great Divergence". Closing the economies of the East during the Early Modern Era was one of the main economic policy mistake ever made.

\section{Chief conclusions}

1) Despite the geographical proximity and easiness of transportation between China and Japan, no statistical evidence of grain market integration between the two countries is found. This finding is somewhat unexpected and contrasts with the increasing intracontinental and inter-continental integration of grain markets observed in the West before 1792 (“Early Globalization”) and after the 1840s (canonical globalization). Historical evidence confirms that the two large Eastern markets for grain were disconnected: no significant trade in rice between China and Japan on permanent basis has been recorded. That neither Korea was integrated with its neighbors is the most likely outcome of the policy of seclusion followed by the Choson dynasty from mid seventeenth century until late into the nineteenth century. "Early Globalization", then, turns out to be a form of Western exceptionalism. In other words, expanding the argument proposed by Acemoglu et al. (2005), the institutional framework established in Early Modern Europe permitted, if unevenly, a widespread diffusion of the positive effects of trade on economic growth. To a lesser extent and later, this is also the case of countries with more absolutist regimes than those of Great Britain, the Netherlands and the US, such as Spain, Italy, France, etc.

2) However, in neither China nor Japan were domestic markets disintegrated. At some point during the period under consideration, many markets (e.g., the Yangtze river delta or western prefectures of Honshu) were roughly as integrated as many advanced European regions (e.g. Southern England). Our findings, then, confirm previous research by Shiue and Keller (2007) and Bassino (2007). However, we also find that: a) in China, market integration decreases from the 1840s on; b) a similar trend (albeit less intense) is observed in Japan form the 1830 to the early 1860s. These long-term dynamics are opposed to the one followed by most national markets in Western 
countries before the late nineteenth-century "protectionist backlash" (Federico and Persson, 2010).

3) The state played a central role in the functioning of grain markets in China. Besides regulating foreign trade, it mobilized a significant amount of the grain supply through the tribute in kind levied on some provinces, accumulated significant stocks to be distributed through the vast network of "evernormal granaries”, occasionally sold at below-market prices or gave tax relief to some provinces, etc. In Japan, apart from restricting foreign trade and controlling the means of transportation that could be used for shipments, the state performed a lesser role in grain circulation. On the contrary, daimyos and big merchants in Osaka were the main agents operating in a sophisticated market that was ultimately based upon the collection of feudal rents in kind and its distribution for sales across the country. With all due qualifications, markets forces were generally more important in the West as a whole throughout the eighteenth and nineteenth centuries. Thus, domestic market integration may be achieved through different combinations of agents and policies. In turn, each of these combinations has specific effects on economic growth.

4) We identify some important differences between West and East regarding market integration: geo-economic scope (intra-continental and inter-continental versus national); evolution over time (secular progress versus reversal in the nineteenth century); and agents and policies (market forces versus state and others as leading forces) and policies (relative openness to foreign trade versus relative closeness). As a result, East and West were dissimilar in terms of market integration before and after the Industrial Revolution.

5) That dissimilarity had implications for the appearance of modern economic growth. In our interpretation, the above-mentioned differences support the notion that the level of intra- and intercontinental of market integration encapsulated by the term “early globalization”: a) preceded rather than succeeded the Industrial Revolution in the West; b) contributed to, albeit did not cause, the "Great Divergence” between East and West. "Early Globalization” soon started to deliver direct and indirect economic benefits that were not shared by the East. A higher integration of grain markets between China, Korea and Japan in the eighteenth century would have been not only mutually beneficial, but also technically and economically possible. It did not happen because of political reasons. By closing their economies in the Early Modern Era, the East governments might have committed one of the biggest economic policy mistakes ever 
made, being the lost "early globalization" just part -and probably not the most important part- of the total cost in terms of economic growth. 


\section{References}

Akaike, H. (1974), "A new look at the statistical model identification", IEEE Transactions on Automatic Control, 19, 6, pp. 716-723.

Acemoglu, D., Johnson, S. and Robinson, J. (2005), "The Rise of Europe: Atlantic Trade, Institutional Change, and Economic Growth, The American Economic Review, 95, 3, pp. 546-579.

Allen, R.C., Bassino, J.P., Ma, D., Moll-Murata, C., Van Zanden, J.L. (2010), “Wages, prices, and living standards in China, 1738-1925: in comparison with Europe, Japan, and India”, Economic History Review, 64, 1, pp. 8-38.

Bassino, J.P. (2007), “Market Integration and Famines in Early Modern Japan, 17171857”, http://federation.ens.fr/ydepot/semin/texte0708/BAS2007MAR.pdf

Bassino, J.P., Broadberry, S., Fukao, K., Gupta, B. and Takashima, M. (2011), “Japan and the Great Divergence, 730-1870",

http://www2.lse.ac.uk/economicHistory/pdf/Broadberry/JapanGreatDivergence.pdf

Bernhofen, D.M. and Brown, J.C. (2005), "An empirical Assessment of the Comparative Advantage Gains from Trade: Evidence from Japan”, American Economic Review, 95, 1, pp. 208-225.

Bolt, J. and Van Zanden, J.L. (2013), “The First Update of the Maddison Project; ReEstimating Growth Before 1820” Maddison-Project Working Paper WP-4.

Brandt, L., Ma, D. and Rawski, T. (2012), "From Divergence to Convergence: Reevaluating the History Behind China's Economic Boom”, Department of Economic History, London School of Economics, Working Papers No. 158/12

De Vries, J. (2010). “The limits of globalization in the early modern world,” The Economic History Review, 63, pp. 710-733. 
Dobado, R., García-Hiernaux, A. y Guerrero, D. (2012), “The Integration of Grain Markets in the Eighteenth Century: Early Rise of Globalization in the West”, Journal of Economic History, 72, 3, pp. 671-707.

Ejrnaes, M. and Persson, K. G. (2000), "Market integration and transport costs in France 1825-1903: A threshold error correction approach to the law of one price,” Explorations in Economic History, 37(2):149-173.

Federico, G. (2008), “The first European grain invasion: a study in the integration of the European market, 1750-1870,” UI Working Papers HEC No. 2008/01, European University Institute.

Federico, G. and Persson, K. G. (2010), "Market Integration and Convergence in the World Wheat Market, 1800-2000”, Discussion Papers, Department of Economics, University of Copenhagen, 06-10.

Findlay, R. and O’Rourke, K. H. (2007). Power and Plenty. Princeton University Press, Princeton.

Flynn, D. O. and Giráldez, A. (2004). "Path dependence, time lags and the birth of globalisation: A critique of O’Rourke and Williamson,” European Review of Economic History, 8, 1, pp. 81-108.

Földváry, P. and van Leeuwen, B. (2011), "What can price volatility tell us about market efficiency? Conditional heteroscedasticity in historical commodity price series," Cliometrica, 5, 2, pp.165-186.

Frank, A. G. (1998), ReOrient. Global Economy in the Asian Age, University of California Press, Berkeley.

Goldstone, J.A. (2008), Why Europe? The Rise of the West in World History 1500-1850, McGraw-Hill, New York. 
Hannan, E. J., and Quinn B. G. (1979), “The Determination of the Order of an Autoregression”, Journal of the Royal Statistical Society B series, 41, pp. 190-195.

Jones, E., 1981. The European Miracle: Environments, Economies and Geopolitics in the History of Europe and Asia. Cambridge University Press, Cambridge.

Keller, W., Li, B. and Shiue C. H. (2012),"Shanghai's Trade, China's Growth: Continuity, Recovery, and Change since the Opium War," CEPR Discussion Papers 8808, Center for Economic Policy Research.

Landes, D. S. (1998), The Wealth and Poverty of Nations: Why Some Are So Rich and Some So Poor, W. W. Norton \& Company, New York.

--(2006), “Why Europe and the West? Why Not China?”, Journal of Economic Perspectives, 20, 2, pp. 3-22.

Li, Lillian M. (200), “Integration and Disintegration in North China's Grain Markets, 1738-1911”, The Journal of Economic History, 60, 3, pp. 665-699.

-- (2007), Fighting Famine in North China, Stanford University Press, Stanford.

Li, B.and Van Zanden, J. L. (2012), "Before the Great Divergence? Comparing the Yangzi Delta and the Netherlands at the Beginning of the Nineteenth Century”, The Journal of Economic History, 72, 4, pp. 956-989.

Maddison, A. (2007a), The Contours of the World Economy, 1-2030 AD. Essays in Macro-Economic History, Oxford University Press, Oxford.

-- (2007b), Chinese Economic Performance in the Long Run, 960-2030, $2^{\text {nd }}$ edition, OECD, Paris.

Millar, A.E. (2011), "Your Beggarly Commerce! Enlightenment European views of the China trade" in Guido Abbattista (editor), Encountering Otherness. Diversities and Transcultural Experiences in Early Modern European Culture, University of Trieste Press, Trieste, pp. 205-222.

Morris, I. (2010), Why the West Rules-For Now, Farrar, Straus and Giroux, New York. 
O’Rourke, K. H. (2006). “The worldwide economic impact of the French Revolutionary and Napoleonic Wars, 1793-1815,” Journal of Global History, 1, pp. 123-149.

O’Rourke, K. H. and Williamson, J. G. (1999). Globalization and History. MIT Press, Cambridge, Mass.

-- (2002a). “When did globalization begin?” European Review of Economic History, 6, pp. 23-50.

-- (2002b). “After Columbus: Explaining Europe’s Overseas Trade Boom, 1500-1800,” Journal of Economic History, 62, 2, pp. 417-456.

-- (2004). “Once more: when did globalization begin?” European Review of Economic History, 4, pp. 109-117.

Persson, K. G. (1999). Grain Markets in Europe, 1500-1900: Integration and Deregulation. Cambridge University Press, Cambridge.

Pomeranz, K. (2000), The Great Divergence: China, Europe, and the Making of the Modern World Economy, Princeton University Press, Princeton.

Shiue, C. H. and Keller, W. (2007), "Markets in China in the Eve of the Industrial Revolution”, The American Economic Review, 97, 4, pp. 1189-1216.

-- (2012), “Shanghais’s Trade, China’s Growth: Continuity, Recovery, and Change since the Opium War”, Discussion Paper No. 8808, Centre for Economic Policy Research.

Shin, D. W. and Fuller, W. A. (1998). "Unit root test based on unconditional maximum likelihood estimation for the autoregressive moving average," Journal of Time Series Analysis, 19, 5, pp. 591-599.

Vaporis, C. N. (1994), Breaking barriers: travel and the state in early modern Japan, Harvard East Asian Monographs, Harvard University Press, Cambridge. Mass.

Vries, P.H.H., 2001. “Are Coal and Colonies Really Crucial? Kenneth Pomeranz and the Great Divergence”, Journal of World History 12 (2), 407-446. 
-- 2003. Via Peking Back to Manchester: Britain, the Industrial Revolution and China. CNWS Publications, Leiden.

Weber, M. (1905:1930), The Protestant ethic and the spirit of capitalism, Unwin, London.

Will, P.E. (1990), Bureaucracy and Famine in Eighteenth Century China, Stanford University Press, Stanford.

Wong, R. B. (1997), China Transformed: Historical Change and the Limits of European Experience, Cornell University Press, Ithaca. 


\section{Figure 1: Market Integration in the West (London as the numéraire),}

1737-1896.

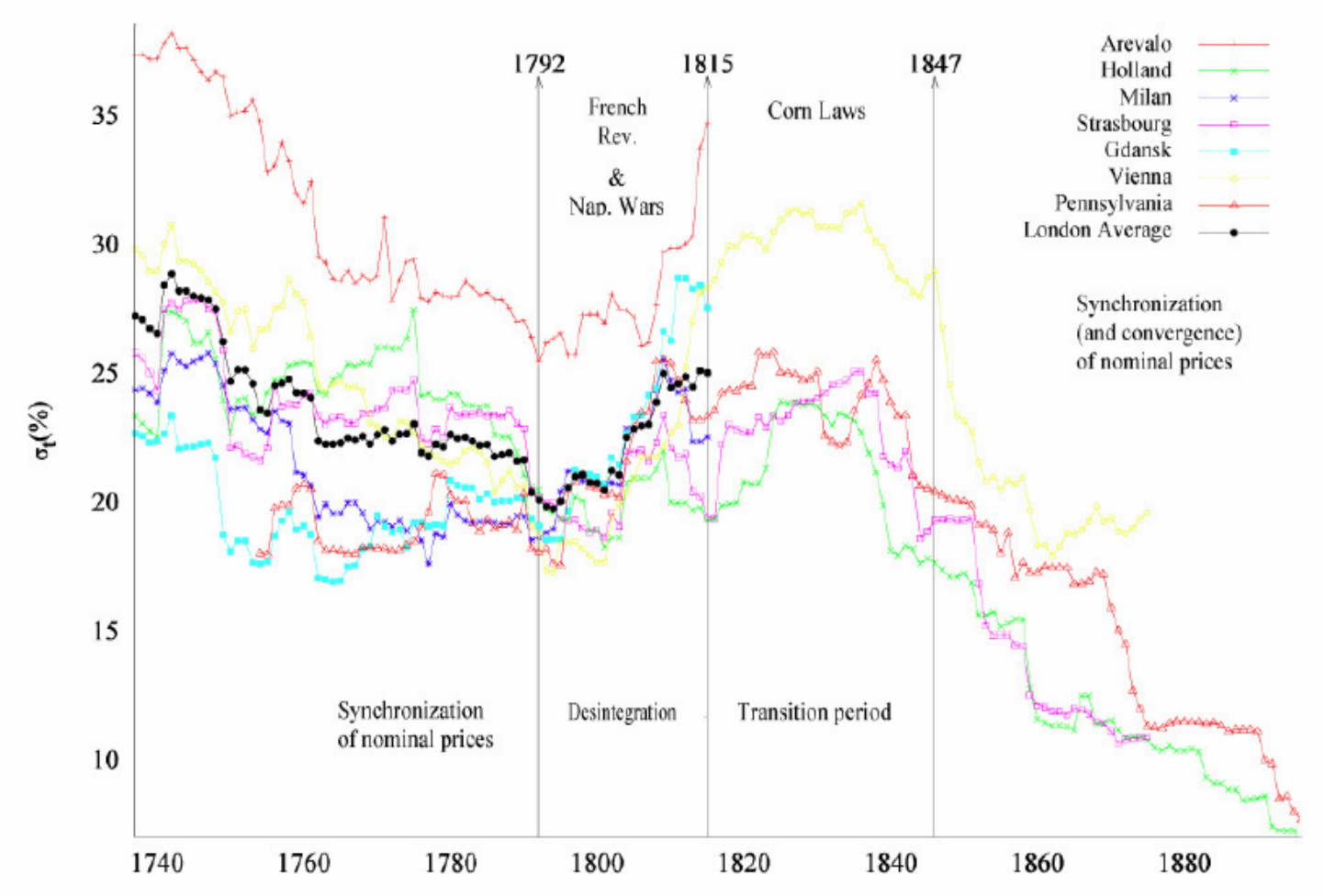

Note: The series are the (log) relative price residual standard deviation calculated using rolling windows span of $t=35$. London average is the mean of the other series (the residual standard deviation of the (log) relative price of $\mathrm{A} / \mathrm{L}, \mathrm{H} / \mathrm{L}, \mathrm{M} / \mathrm{L}, \mathrm{S} / \mathrm{L}, \mathrm{G} / \mathrm{L}, \mathrm{V} / \mathrm{L}, \mathrm{P} / \mathrm{L}$ ) at each period $t$.

Source: See Appendix 1. 


\section{Figure 2: Market Integration in the West (Pennsylvania) as the numéraire), 1754-1896.}

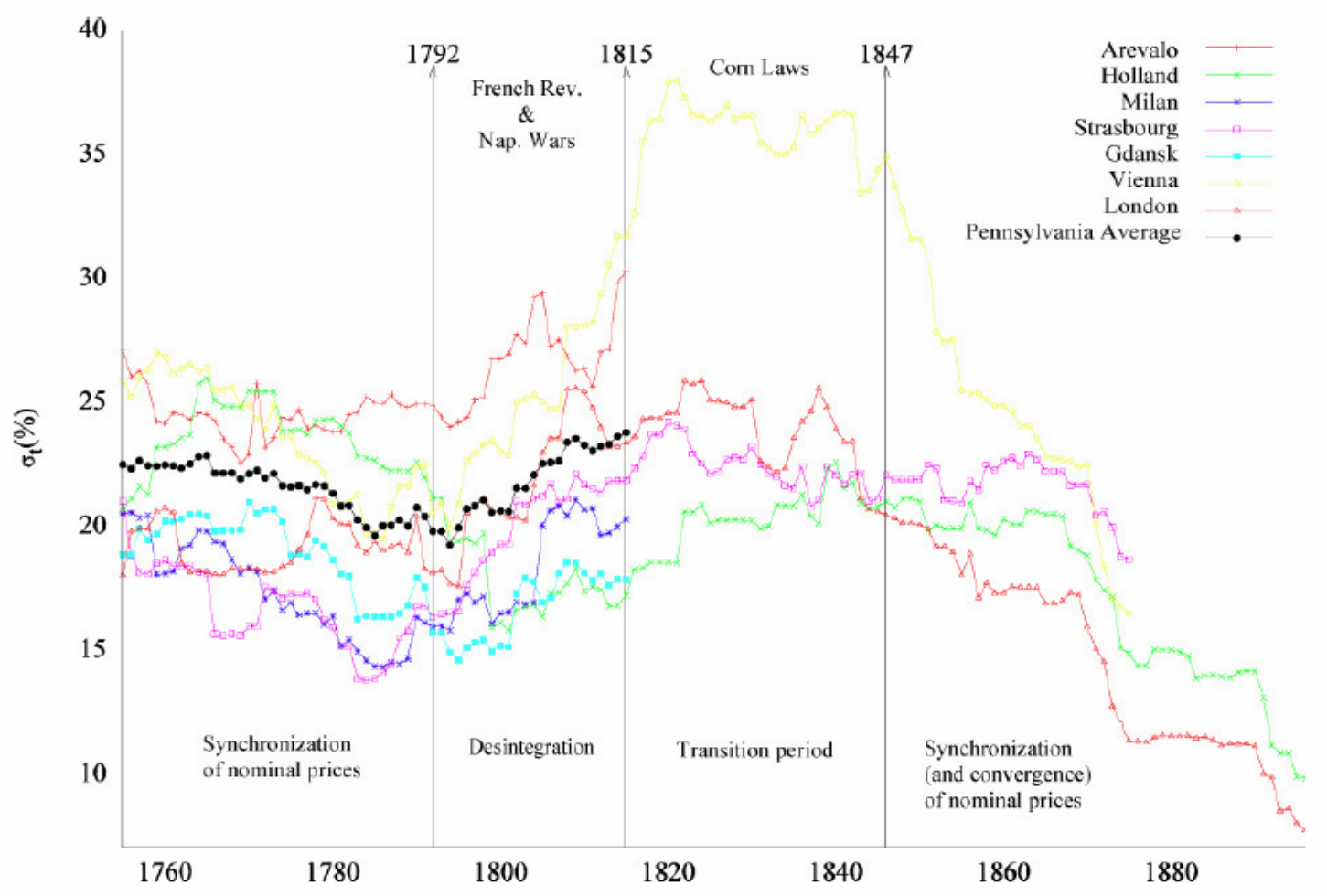

Note: The series are the (log) relative price residual standard deviation calculated using rolling windows span of $t=35$. London average is the mean of the other series (the residual standard deviation of the (log) relative price of A/P, H/P, M/P, S/P, G/P, V/P, L/P) at each period $t$.

Source: See Appendix 1. 
Figure 3: Market integration in England, 1734-1816.

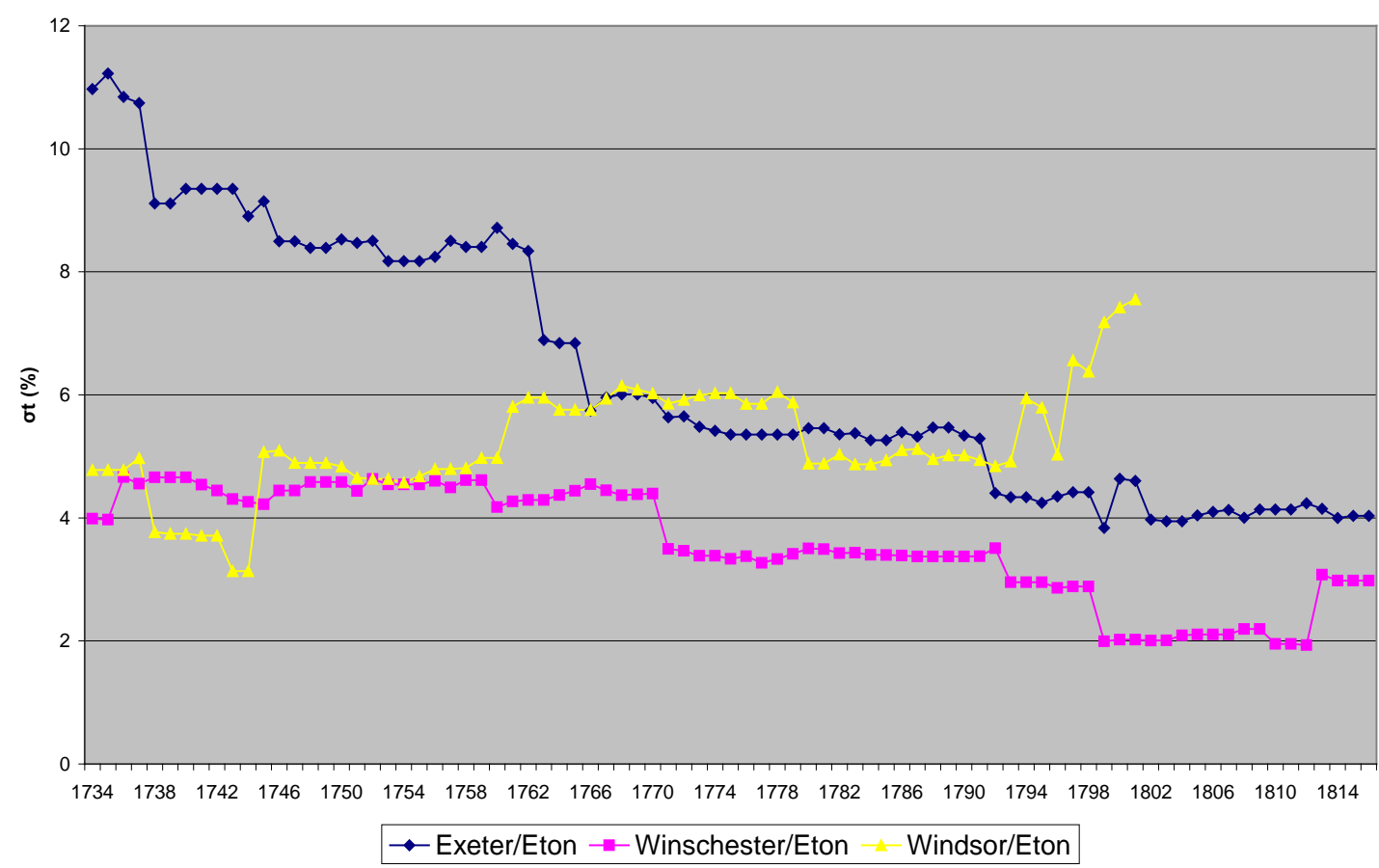

Source: See Appendix 1.

Figure 4: Integration of selected rice markets in China, 1778-1910.

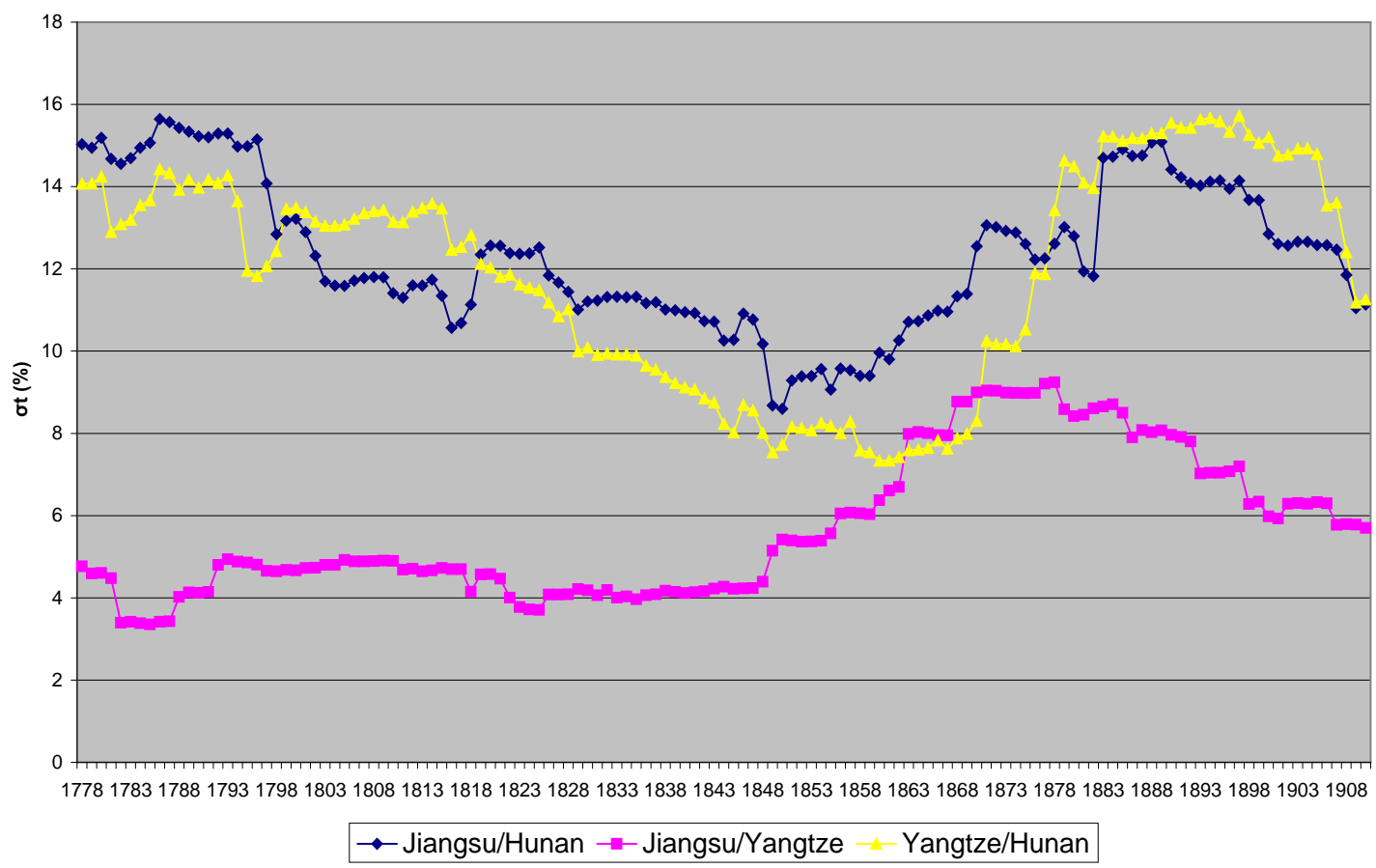

Source: See Appendix 
Figure 5: Rice market integration in Japan, 1744-1863.

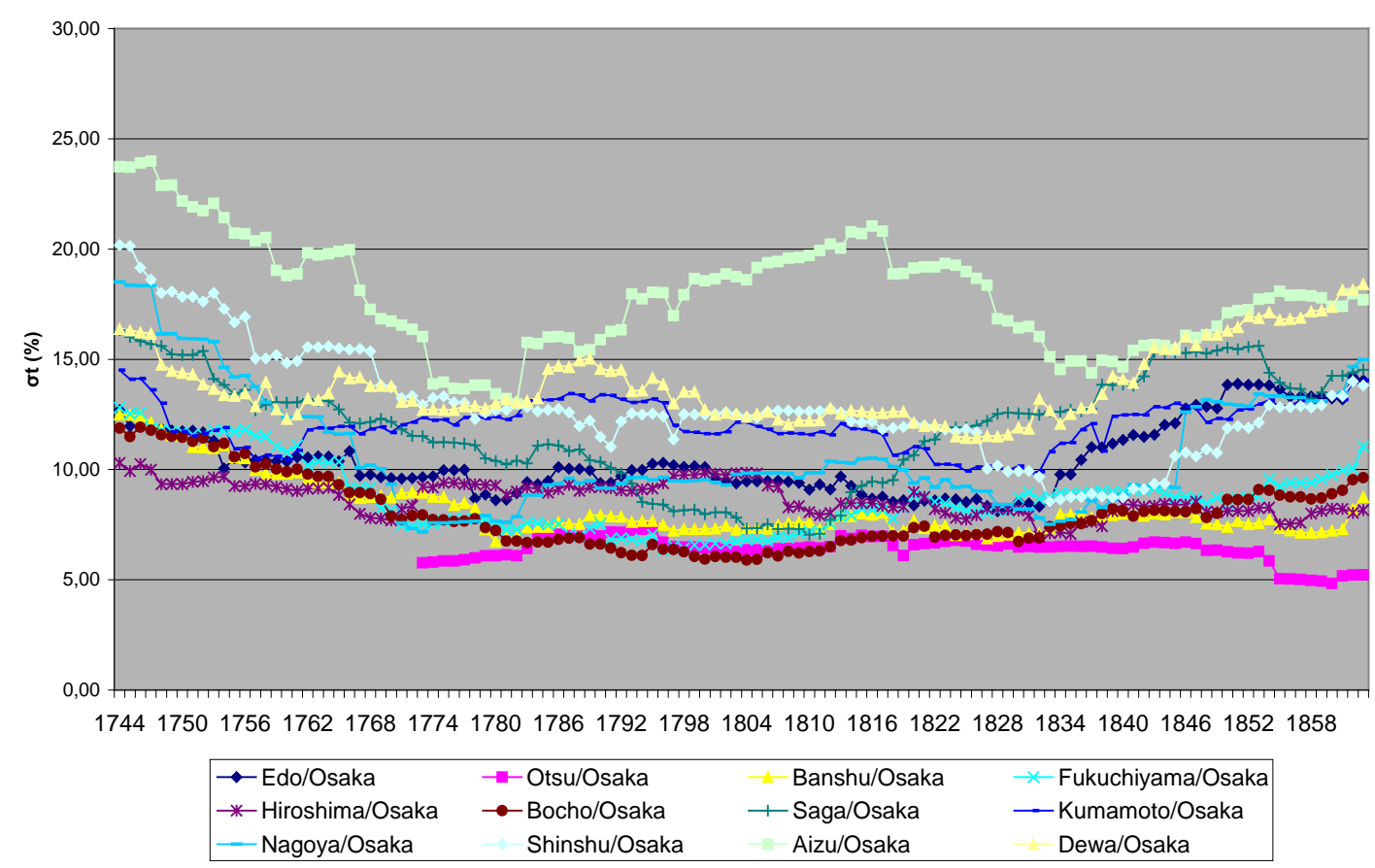

Source: See Appendix 1.

Figure 6: Grain market integration in East and West, 1734-1910.

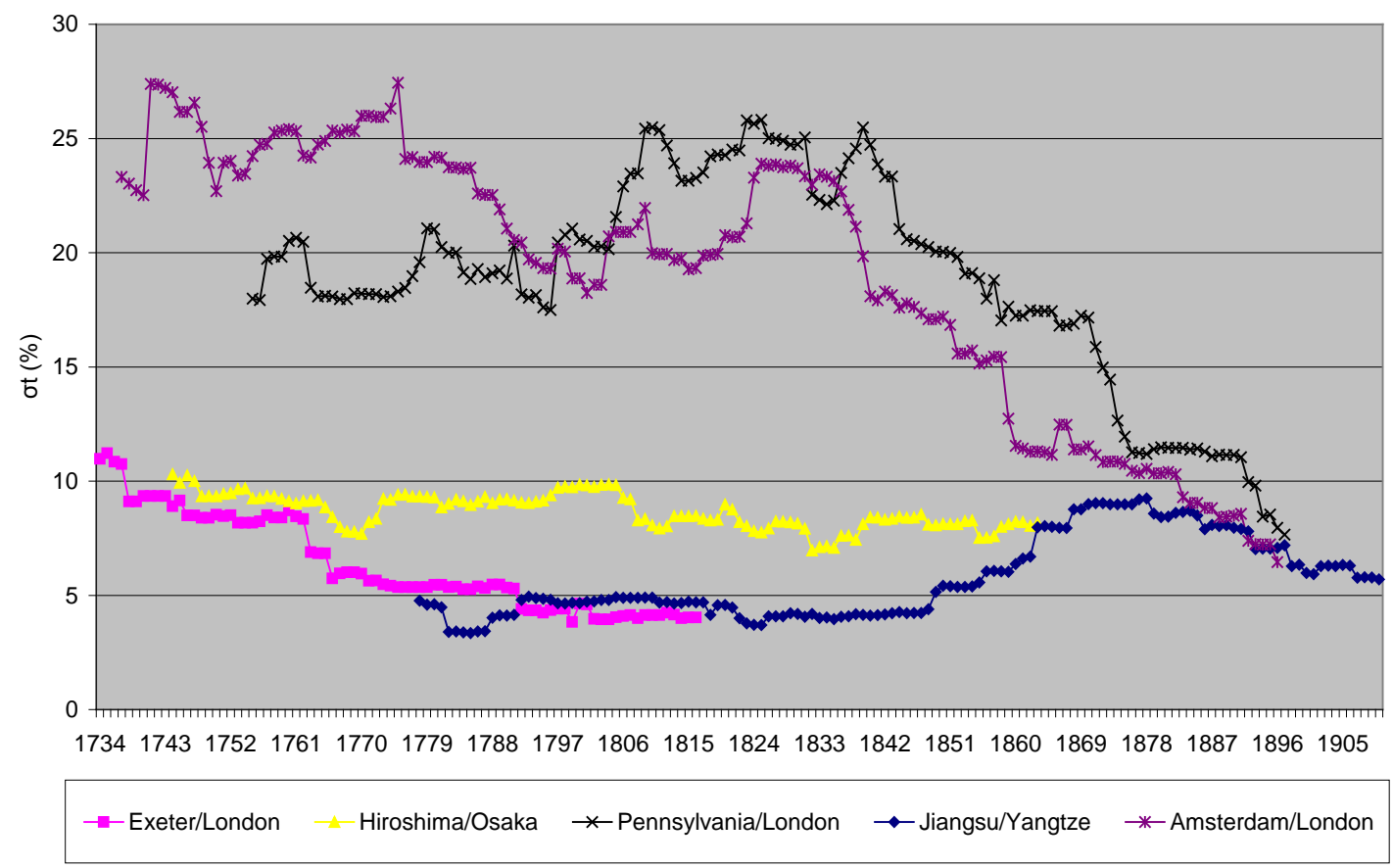

Source: See Appendix 1. 
Table 1. Methodological scheme

\begin{tabular}{|c|c|c|c|c|}
\hline Step & Hypothesis & $\begin{array}{l}\text { Interpretation of } \\
\text { the hypothesis }\end{array}$ & $\begin{array}{c}\text { Econometric } \\
\text { tools }\end{array}$ & Results \\
\hline 1 & I(1) nominal prices ${ }^{1}$ & $\begin{array}{l}\text { Some shifts in supply or } \\
\text { demand imply that price } \\
\text { adjustments are necessary to } \\
\text { clear the market in the long } \\
\text { run }\end{array}$ & $\begin{array}{l}\text { ARMA models, } \\
\text { nonstationarity } \\
\text { and } \\
\text { noninvertibility } \\
\text { tests }^{1}\end{array}$ & $\begin{array}{l}\text { Rejects: None } \\
\text { Accepts: All the } \\
\text { Japanese, Chinese, } \\
\text { European and American } \\
\text { series. }\end{array}$ \\
\hline 2 & $\mathrm{I}(0)$ relative prices ${ }^{1}$ & $\begin{array}{l}\text { Nominal prices are } \\
\text { cointegrated (with } \\
\text { cointegrating parameter } \\
\text { equal to -1). If so, they follow } \\
\text { the Law of One Price (weak } \\
\text { form) }\end{array}$ & $\begin{array}{l}\text { ARMA models, } \\
\text { nonstationarity } \\
\text { and } \\
\text { noninvertibility } \\
\text { tests }^{1}\end{array}$ & $\begin{array}{l}\text { Rejects: Between } \\
\text { Chinese and Japanese } \\
\text { rice series. } \\
\text { Accepts: Between all the } \\
\text { wheat series (Europe } \\
\text { and America). } \\
\text { Between all Chinese rice } \\
\text { series. } \\
\text { Between all Japanese } \\
\text { rice series. }\end{array}$ \\
\hline 3 & $\begin{array}{l}\text { Decreasing } \\
\text { dispersion of } \\
\text { relative prices' } \\
\text { unpredicted shocks }{ }^{2}\end{array}$ & $\begin{array}{l}\text { Synchronization of the } \\
\text { nominal prices. Market } \\
\text { integration through the } \\
\text { reduction of arbitrage } \\
\text { possibilities during the } \\
\text { nineteenth Century. }\end{array}$ & Graphical tools ${ }^{2}$ & $\begin{array}{l}\text { Rejects: In China and } \\
\text { Japan. } \\
\text { Accepts: In Europe and } \\
\text { Pennsylvania. }\end{array}$ \\
\hline
\end{tabular}

Notes: ${ }^{1}$ The I(1) and I(0) properties of the time series are tested with the nonstationarity Shin and Fuller (1981) test and confirmed with the noninvertibility Davis et al. (1995) test. ${ }^{2}$ Decreasing dispersion is tested using graphical tools. ${ }^{3}$ The markets are defined in the section 2. 


\section{Appendix 1: Sources of data on grain prices.}

\section{Markets in the East:}

Yangtze Delta, 1638-1935: Wang, Y. (1992), "Secular Trends of Rice Prices in the Yangzi Delta, 1638-1935”, Thomas G. Rawski and Lillian M. Li (eds.), Chinese History in Economic Perspective, University of California Press, Berkeley, etc., pp. 3568. Original prices in taels (37.3 grams of silver) of silver per shi (103.5 liters) converted into grams of silver per liter.

Jiangsu and Hunan, 1736-1911: Qing-era Grain Price Database, Institute of Modern History. Academia Sinica:

(http://www.mh.sinica.edu.tw/PGDigitalDB_Detail.aspx?htmContentID=29\&lang=enU S) Original prices in taels (37.3 grams of silver) of silver per shi (103.5 liters) converted into grams of silver per liter. These data were kindly facilitated by Cong Liu whose generous help we acknowledge.

Aizu, Banshu (rural), Bocho, Dewa, Osaka, Edo, Fukuchiyama, Hiroshima, Kumamoto, Nagoya and Shinshu, 1710-1863: Original prices in ryos (60 monmes) or monmes (3.75 grams of silver) per koku (180.391 liters) converted into grams of silver per liter. Source is http://www.iisg.nl/hpw/data.php\#japan, accessible through the web page of the International Institute of Social History. We appreciate its generosity for making available these data to the international academic community

\section{Markets in the West:}

See Dobado et al. 2102. 